\title{
Thermoelectric Properties of Inhomogeneous Ceramics Based on the Layered Calcium Cobaltate
}

\author{
Andrei Klyndyuk $^{1, *}$, Ekaterina Chizhova ${ }^{1}$, Irina Matsukevich ${ }^{2}$, Ekaterina Tugova ${ }^{3}$ \\ ${ }^{1}$ Department of Physical, Colloid and Analytical Chemistry, Belarusian State Technological University, Belarus Republic \\ ${ }^{2}$ Laboratory of Magnesium Compounds, The Institute of General and Inorganic Chemistry of National Academy of Sciences of Belarus, \\ Belarus Republic \\ ${ }^{3}$ Laboratory of New Inorganic Materials, Ioffe Physical-Technical Institute of Russian Academy of Sciences, Russian Federation
}

Received September 27, 2019; Revised November 18, 2019; Accepted November 25, 2019

Copyright $\subseteq 2019$ by authors, all rights reserved. Authors agree that this article remains permanently open access under the terms of the Creative Commons Attribution License 4.0 International License

\begin{abstract}
The effect of cationic composition and sintering conditions on the electrotransport and thermoelectric properties of $\mathrm{Ca}_{3} \mathrm{Co}_{x} \mathrm{O}_{9+\delta}(x=3.8,4.0$, and 4.2) had been investigated. It had been found that increase of cobalt oxide content in the samples increase their electrical conductivity, creation of phase inhomogeneity improves their thermo-EMF coefficient, and sintering above temperature of peritectoid decomposition increase their apparent density, which, in the whole, improves thermoelectric properties of ceramics based on the layered calcium cobaltate $\mathrm{Ca}_{3} \mathrm{Co}_{4} \mathrm{O}_{9+\delta}$. So, power factor values of phase inhomogeneous ceramics $\mathrm{Ca}_{3} \mathrm{Co}_{4.2} \mathrm{O}_{9+\delta}$, sintered in air below and above temperature of peritectoid decomposition of $\mathrm{Ca}_{3} \mathrm{Co}_{4} \mathrm{O}_{9+\delta}$, at $800^{\circ} \mathrm{C}$ were equal 255 and $273 \mu \mathrm{W} /\left(\mathrm{m} \cdot \mathrm{K}^{2}\right)$ respectively, which was 2.1 and 2.4 times larger than for the $\mathrm{Ca}_{3} \mathrm{Co}_{4} \mathrm{O}_{9+\delta}$. It had been also found that sintering of phase inhomogeneous ceramics both in oxidizing or reducing atmospheres resulted in improving of its functional properties. So, power factor values of $\mathrm{Ca}_{3} \mathrm{Co}_{3.8} \mathrm{O}_{9+\delta}$ (sintered in oxygen at $970^{\circ} \mathrm{C}$ ) and $\mathrm{Ca}_{3} \mathrm{Co}_{4.2} \mathrm{O}_{9+\delta}$ (sintered in nitrogen at $920^{\circ} \mathrm{C}$ ) at $800^{\circ} \mathrm{C}$ were equal 422 and $378 \mu \mathrm{W} /\left(\mathrm{m} \cdot \mathrm{K}^{2}\right)$ respectively, which was 3.5 and 3.1 times larger than for the $\mathrm{Ca}_{3} \mathrm{Co}_{4} \mathrm{O}_{9+\delta}$.
\end{abstract}

Keywords Layered Calcium Cobaltate, Phase Inhomogeneity, Thermoelectrics, Sintering Conditions, Electrical Conductivity, Thermo-EMF, Power Factor

\section{Introduction}

The growth of global energy consumption and the negative environmental impact of many modern energy conversion technologies (for example, the burning of hydrocarbon fuels) have led to increased activity in the search for alternative energy sources. A huge renewable source of energy is the heat evolved into the environment during the work of industrial enterprises, vehicles, as well as various plants and units. This heat can be directly and effectively converted into electrical energy using thermoelectric generators, the creation of which requires so-called thermoelectric materials (thermoelectrics), which possesses high values of electrical conductivity and thermo-EMF coefficient and have low thermal conductivity [1]. Chalcogenides of heavy metals are traditional thermoelectrics, but these materials are expensive, toxic and unstable in air at high temperatures.

The indicated drawbacks are largely absent for oxide thermoelectrics, including materials based on the layered calcium cobaltate $\mathrm{Ca}_{3} \mathrm{Co}_{4} \mathrm{O}_{9+\delta}$, which in recent years are considered as a promising basis for the development of $p$-branches of high-temperature thermoelectric generators $[2,3]$. The functional (thermoelectric) characteristics of ceramics based on the $\mathrm{Ca}_{3} \mathrm{Co}_{4} \mathrm{O}_{9+\delta}$ can be essentially improved by using instead of the traditional ceramic methods the "soft" low-temperature synthesis methods [4, 5], using special techniques for sintering ceramics - hot pressing [6], spark plasma sintering [7-9], and also by partial substitution of calcium ions in it by bismuth [3, 1012] or rare earth elements ions [3, 13, 14] or of cobalt ions by $3 d$-metal ions $[3,15,16]$. It was shown in [11, 17-19] that thermoelectric characteristics of oxide ceramics can be improved by creating phase inhomogeneity in it.

In ceramics based on layered calcium cobaltate, phase inhomogeneity can be created in various ways - by introducing a second, impurity phase into the mixture at the stage of synthesis or sintering [20-22], by varying the cationic stoichiometry of the initial mixture so that the target composition is outside the $\mathrm{Ca}_{3} \mathrm{Co}_{4} \mathrm{O}_{9+\delta}$ homogeneity region [23] (according to [24], in air, layered calcium cobaltate can be obtained in the composition range 
$\left.\mathrm{Ca}_{3} \mathrm{Co}_{3.87} \mathrm{O}_{9+\delta}-\mathrm{Ca}_{3} \mathrm{Co}_{4.07} \mathrm{O}_{9+\delta}\right)$ as well as by thermal treatment (annealing) of ceramics at temperatures exceeding the temperature of peritectoid decomposition of $\mathrm{Ca}_{3} \mathrm{Co}_{4} \mathrm{O}_{9+\delta}\left(T_{p}=926^{\circ} \mathrm{C}\right.$ in air [24]) by the reaction $\mathrm{Ca}_{3} \mathrm{Co}_{4} \mathrm{O}_{9+\delta} \rightarrow \mathrm{Ca}_{3} \mathrm{Co}_{2} \mathrm{O}_{6}+(\mathrm{Co}, \mathrm{Ca}) \mathrm{O}$. In this work, the last two approaches were used to create phase inhomogeneity in ceramics based on layered calcium cobaltate.

The aim of this work was to study the influence of the cationic composition and thermal prehistory of ceramics based on $\mathrm{Ca}_{3} \mathrm{Co}_{4} \mathrm{O}_{9+\delta}$ on its phase composition, physicochemical and functional properties, as well as to study the possibility of improving the thermoelectric (functional) characteristics of materials based on the layered calcium cobaltate by creating of phase inhomogeneity in it.

\section{Materials and Methods}

Ceramics with a nominal composition of $\mathrm{Ca}_{3} \mathrm{Co}_{3.8} \mathrm{O}_{9+\delta}$, $\mathrm{Ca}_{3} \mathrm{Co}_{4} \mathrm{O}_{9+\delta}$, and $\mathrm{Ca}_{3} \mathrm{Co}_{4.2} \mathrm{O}_{9+\delta}$, was obtained by the citrate method according to the procedure described in $[14,16]$ using $\mathrm{Ca}\left(\mathrm{NO}_{3}\right)_{2} \cdot 4 \mathrm{H}_{2} \mathrm{O}, \mathrm{Co}\left(\mathrm{NO}_{3}\right)_{2} \cdot 6 \mathrm{H}_{2} \mathrm{O}$ (analytical grade), and citric acid $\mathrm{C}_{6} \mathrm{H}_{8} \mathrm{O}_{7}$ (analytical grade) as the starting reagents. At the final stage, the samples were sintered for 6 $\mathrm{h}$ in air (A serie) at temperatures of $920^{\circ} \mathrm{C}\left(T<T_{p}\right)$ and $970^{\circ} \mathrm{C}\left(T>T_{p}\right)$, in oxygen (O serie) at temperatures of $970^{\circ} \mathrm{C}\left(T<T_{p}\right)$ and $1020^{\circ} \mathrm{C}\left(T>T_{p}\right)$, and in nitrogen ( $\mathrm{N}$ serie) at temperatures of $890^{\circ} \mathrm{C}\left(T<T_{p}\right), 920^{\circ} \mathrm{C}$ and $970^{\circ} \mathrm{C}\left(T>T_{p}\right)$ followed by slow cooling to room temperature.

The phase composition of the samples and the crystal structure parameters of predominant phases in them were determined using X-ray diffraction analysis (XRD) (Bruker D8 XRD Advance X-ray diffractometer, CuK $\alpha-$ radiation, Ni filter).

The microstructure of sintered ceramics and its chemical composition was studied by means of JSM-5610 LV scanning electron microscope with EDX JED-2201 chemical analysis system (JEOL, Japan) using a reflected electron detector (accelerating voltage $-20 \mathrm{kV}$ ) in low vacuum mode ( $p=1 \mathrm{~Pa}$ ) and using Fei Company Quanta 200 instrument equipped with an EDAX attachment. The apparent density of the samples ( $\rho_{\text {exp }}$ ) was determined on their mass and geometric dimensions.

The electrical conductivity $(\sigma)$ and thermo-EMF coefficient $(S)$ of sintered ceramics based on the layered calcium cobaltate $\mathrm{Ca}_{3} \mathrm{Co}_{4} \mathrm{O}_{9+\delta}$ were studied in air in the temperature range of $300-1100 \mathrm{~K}$ [25]. The values of apparent acxtivation energy of their electrical conductivity were determined from linear parts of $\ln (\sigma \cdot T)=f(T)$ dependencies, taking into account that temperature dependencies of electrical conductivity of layered calcium cobaltate $\mathrm{Ca}_{3} \mathrm{Co}_{4} \mathrm{O}_{9+\delta}$ and its derivatives above room temperature usually obey equation $\sigma=$ $\left(\sigma_{0} / T\right) \cdot \exp \left[-E_{A} /\left(k_{B} \cdot T\right)\right]$, where $\sigma_{0}$ is temperature independent constant, $E_{A}$ is apparent activation energy of electrical conductivity, $k_{B}$ is Boltzmann's constant, and $T$ is absolute temperature $[5,23]$. The power factor $(P)$ values were calculated by the formula $P=S^{2} \cdot \sigma$.

\section{Results and Their Discussion}

Taking into account the phase diagram of the $\mathrm{CaO}-\mathrm{CoO}$ quasibinary system in air [24], it was expected that all samples of A serie, except for $\mathrm{Ca}_{3} \mathrm{Co}_{4} \mathrm{O}_{9+\delta}$ ceramics, sintered at temperature of $920^{\circ} \mathrm{C}$, will be non-monophase (Table 1). According to the XRD data (Figure 1, $a$, Table 1), samples of $\mathrm{Ca}_{3} \mathrm{Co}_{3.8} \mathrm{O}_{9+\delta}, \mathrm{Ca}_{3} \mathrm{Co}_{4} \mathrm{O}_{9++}$, and $\mathrm{Ca}_{3} \mathrm{Co}_{4.2} \mathrm{O}_{9+\delta}$ compositions after annealing in air at $920^{\circ} \mathrm{C}$, and sample of $\mathrm{Ca}_{3} \mathrm{Co}_{3.8} \mathrm{O}_{9+\delta}$ composition after annealing in air at $970^{\circ} \mathrm{C}$ were mono-phase, within the accuracy of XRD method, and had the structure of the layered calcium cobaltate $\mathrm{Ca}_{3} \mathrm{Co}_{4} \mathrm{O}_{9+\delta}$ [26] with the lattice constants given in the Table. 1. As can be seen from the Table 1, creation both excess and deficiency of cobalt oxide in the layered calcium cobaltate leads to the increasing of $b_{2}$ parameter (repeatability period in the $a b$-plane of $\mathrm{CoO}_{2}$-layers of $\mathrm{Ca}_{3} \mathrm{Co}_{4} \mathrm{O}_{9+\delta}$ crystal structure [26]). The samples of $\mathrm{Ca}_{3} \mathrm{Co}_{4} \mathrm{O}_{9+\delta}$ and $\mathrm{Ca}_{3} \mathrm{Co}_{4.2} \mathrm{O}_{9+\delta}$ compositions annealed in air at $970^{\circ} \mathrm{C}$ were non-monophase and consisted of calcium cobaltite $\mathrm{Ca}_{3} \mathrm{Co}_{2} \mathrm{O}_{6}$ having a quasi-one-dimensional structure [27, 28] and $\mathrm{Co}_{3} \mathrm{O}_{4}$ oxide [29], with predominant phase of $\mathrm{Ca}_{3} \mathrm{Co}_{2} \mathrm{O}_{6}$ in both cases (Table 1). 

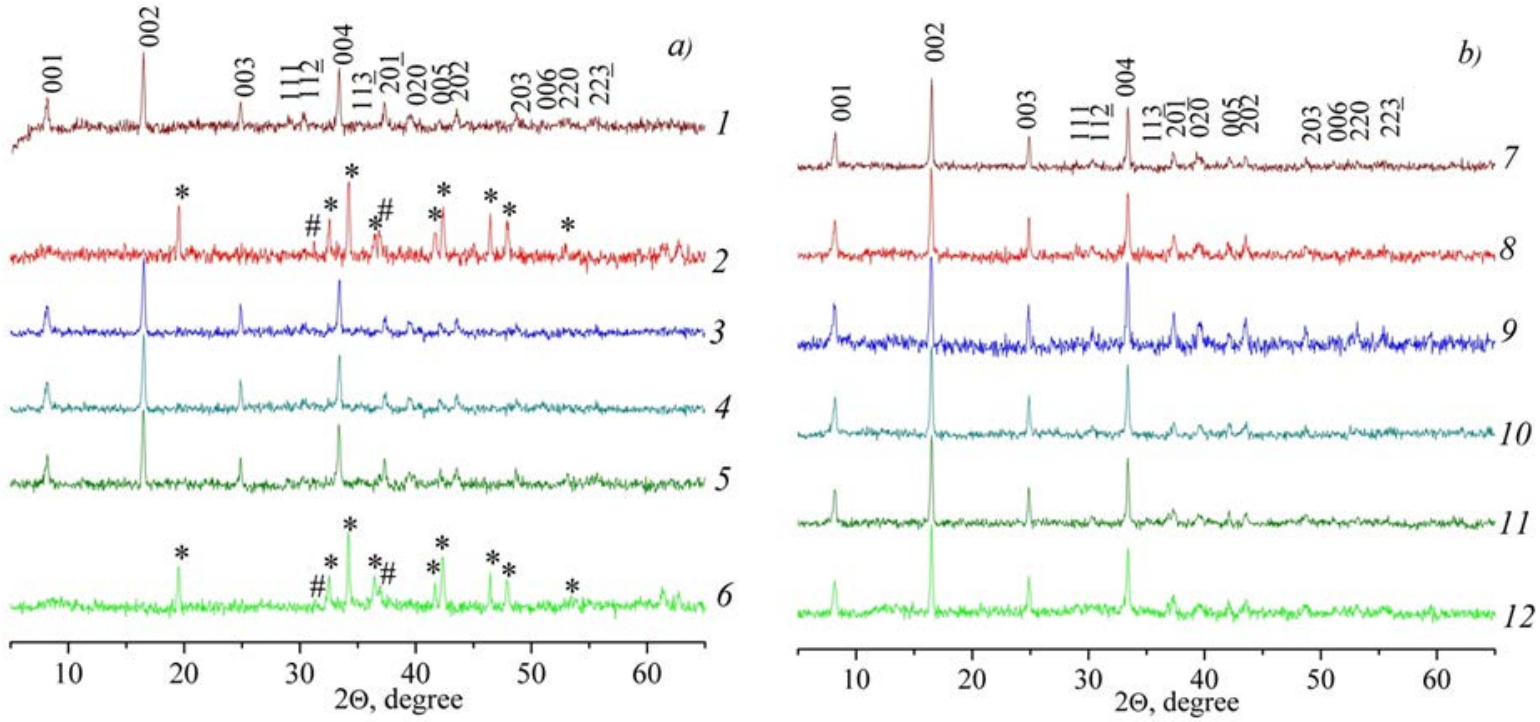

Figure 1. X-ray powder diffractograms $\left(\mathrm{CuK}_{\alpha}\right.$-radiation) of $\mathrm{Ca}_{3} \mathrm{Co}_{4} \mathrm{O}_{9+\delta}(1,2,7,8), \mathrm{Ca}_{3} \mathrm{Co}_{3.8} \mathrm{O}_{9+\delta}(3,4,9,10)$, and $\mathrm{Ca}_{3} \mathrm{Co}_{4.2} \mathrm{O}_{9+\delta}(5,6,11,12)$ samples, annealed in air $(a)$ and oxygen $(b)$ at $920^{\circ} \mathrm{C}(1,3,5), 970^{\circ} \mathrm{C}(2,4,6,7,9,11)$, and $1020^{\circ} \mathrm{C}(8,10,12)$. The Miller indices of $\mathrm{Ca}_{3} \mathrm{Co}_{4} \mathrm{O}_{9+\delta} \mathrm{phase}$ are indicated. Symbols * and \# depict the reflexes of $\mathrm{Ca}_{3} \mathrm{Co}_{2} \mathrm{O}_{6}$ and $\mathrm{Co}_{3} \mathrm{O}_{4}$ phases respectively

Table 1. Apparent density ( $\left.\rho_{\text {app }}\right)$, phase composition and lattice constants $\left(a, b_{1}, b_{2}, c, \beta\right.$, ) of predominant phase in the ceramics based on the layered calcium cobaltate obtained in air (A serie) at different temperatures $T$

\begin{tabular}{|c|c|c|c|c|c|c|c|c|c|c|}
\hline \multirow{2}{*}{ Composition } & \multirow{2}{*}{$T,{ }^{\circ} \mathrm{C}$} & \multirow{2}{*}{$\begin{array}{l}\rho_{\text {app }}, \\
\mathrm{g} / \mathrm{cm}^{3}\end{array}$} & \multicolumn{2}{|c|}{ Phase composition } & \multirow{2}{*}{$\begin{array}{c}\text { Predominant } \\
\text { phase }\end{array}$} & \multicolumn{5}{|c|}{ Lattice constants of predominant phase } \\
\hline & & & Expected & Real* & & $a, \AA$ & $b_{1}, \AA$ & $b_{2}, \AA$ & $c, \AA$ & $\beta,^{\circ}$ \\
\hline $\mathrm{Ca}_{3} \mathrm{Co}_{3.8} \mathrm{O}_{9+\delta}$ & \multirow{3}{*}{920} & 2.87 & $\begin{array}{c}\mathrm{Ca}_{3} \mathrm{Co}_{4} \mathrm{O}_{9+\delta} \\
\mathrm{Ca}_{3} \mathrm{Co}_{2} \mathrm{O}_{6}\end{array}$ & \multirow{3}{*}{$\mathrm{Ca}_{3} \mathrm{Co}_{4} \mathrm{O}_{9+\delta}$} & \multirow{3}{*}{$\mathrm{Ca}_{3} \mathrm{Co}_{4} \mathrm{O}_{9+\delta}$} & $4.823(6)$ & $4.574(7)$ & $2.850(9)$ & 10.83(1) & $97.99(7)$ \\
\hline $\mathrm{Ca}_{3} \mathrm{Co}_{4} \mathrm{O}_{9+\delta}$ & & 2.77 & $\mathrm{Ca}_{3} \mathrm{Co}_{4} \mathrm{O}_{9+\delta}$ & & & $4.837(6)$ & $4.565(7)$ & 2.821(8) & 10.84(1) & $98.28(7)$ \\
\hline $\mathrm{Ca}_{3} \mathrm{Co}_{4.2} \mathrm{O}_{9+\delta}$ & & 2.72 & $\begin{array}{c}\mathrm{Ca}_{3} \mathrm{Co}_{4} \mathrm{O}_{9+\delta} \\
(\mathrm{Co}, \mathrm{Ca}) \mathrm{O}\end{array}$ & & & $4.829(7)$ & $4.566(8)$ & $2.846(9)$ & 10.85(1) & $98.13(8)$ \\
\hline $\mathrm{Ca}_{3} \mathrm{Co}_{3.8} \mathrm{O}_{9+\delta}$ & \multirow{3}{*}{970} & 3.20 & \multirow{3}{*}{$\begin{array}{c}\mathrm{Ca}_{3} \mathrm{Co}_{4} \mathrm{O}_{9+\delta}^{\#}, \\
\mathrm{Ca}_{3} \mathrm{Co}_{2} \mathrm{O}_{6},(\mathrm{Co}, \mathrm{Ca}) \mathrm{O}\end{array}$} & $\mathrm{Ca}_{3} \mathrm{Co}_{4} \mathrm{O}_{9+\delta}$ & $\mathrm{Ca}_{3} \mathrm{Co}_{4} \mathrm{O}_{9+\delta}$ & $4.846(7)$ & $4.567(8)$ & 2.832(9) & 10.84(1) & 97.93(8) \\
\hline $\mathrm{Ca}_{3} \mathrm{Co}_{4} \mathrm{O}_{9+\delta}$ & & 3.01 & & $\mathrm{Ca}_{3} \mathrm{Co}_{2} \mathrm{O}_{6}, \mathrm{Co}_{3} \mathrm{O}_{4}$ & $\mathrm{Ca}_{3} \mathrm{Co}_{2} \mathrm{O}_{6}$ & $10.21(2)$ & - & - & 11.34(6) & - \\
\hline $\mathrm{Ca}_{3} \mathrm{Co}_{4.2} \mathrm{O}_{9+\delta}$ & & 3.11 & & $\mathrm{Ca}_{3} \mathrm{Co}_{2} \mathrm{O}_{6}, \mathrm{Co}_{3} \mathrm{O}_{4}$ & $\mathrm{Ca}_{3} \mathrm{Co}_{2} \mathrm{O}_{6}$ & $10.20(3)$ & - & - & 11.21(7) & - \\
\hline
\end{tabular}

*According to the $\mathrm{X}$-ray data

\#According to [24], at $970^{\circ} \mathrm{C}$ in air this phase is thermodynamically unstable, but can form at slow cooling of the sample to the room temperature due to the peritectoid reaction of $\mathrm{Ca}_{3} \mathrm{Co}_{2} \mathrm{O}_{6}+(\mathrm{Co}, \mathrm{Ca}) \mathrm{O} \rightarrow \mathrm{Ca}_{3} \mathrm{Co}_{4} \mathrm{O}_{9+\delta}$.

Taking in the account on the results of the XRD we can make two conclusions. Firstly, the impurity phases $\left(\mathrm{Ca}_{3} \mathrm{Co}_{2} \mathrm{O}_{6}, \quad(\mathrm{Co}, \mathrm{Ca}) \mathrm{O}\right)$ in the samples $\mathrm{Ca}_{3} \mathrm{Co}_{3.8} \mathrm{O}_{9+\delta}$, $\mathrm{Ca}_{3} \mathrm{Co}_{4.2} \mathrm{O}_{9+\delta}$ sintered at $920^{\circ} \mathrm{C}$ are in amounts lower than the sensitivity of the XRD method. Secondly, the formation of layered calcium cobaltate $\mathrm{Ca}_{3} \mathrm{Co}_{4} \mathrm{O}_{9+\delta}$ from the quasi-one-dimensional phase $\mathrm{Ca}_{3} \mathrm{Co}_{2} \mathrm{O}_{6}$ and solid solution (Co,Ca)O in the samples sintered at $920^{\circ} \mathrm{C}$ at their cooling to the room temperature in mixtures containing an excess of $\mathrm{CaO}$ occurs much faster than in the mixtures of stoichiometric composition (Ca: Co $=3: 4$ ) and in the mixtures containing an excess of cobalt oxide.

The apparent density of ceramics varied within 2.72$3.20 \mathrm{~g} / \mathrm{cm}^{3}$ (Table 1), increased at increasing of their sintering temperature, and the highest values of $\rho_{\text {app }}$ were observed for samples with a lack of cobalt oxide (excess of calcium oxide) having $\mathrm{Ca}_{3} \mathrm{Co}_{3.8} \mathrm{O}_{9+\delta}$ composition.

Taking into account the phase diagram of the $\mathrm{CaO}-\mathrm{CoO}$ quasibinary system in an oxygen atmosphere [24], it was expected that all samples of $\mathrm{O}$ serie, except for $\mathrm{Ca}_{3} \mathrm{Co}_{4} \mathrm{O}_{9+\delta}$ ceramics, sintered in an oxygen atmosphere at $970^{\circ} \mathrm{C}$, will be non-monophase (Table 2). According to the XRD data (Figure 1, b, Table 2), all the obtained samples after annealing were, within the accuracy of XRD method, monophase and had the structure of layered calcium cobaltate $\mathrm{Ca}_{3} \mathrm{Co}_{4} \mathrm{O}_{9+\delta}$ [26] with the crystal structure parameters given in the Table 2. Interestingly, that creation both excess and deficiency of cobalt oxide in the layered calcium cobaltate results in the similar changes of its lattice constants: increasing of $b_{2}$ parameter for the samples sintered at $970^{\circ} \mathrm{C}$ in oxygen (below $T_{p}$ ) and increasing of $a$ parameter and decreasing of $b_{1}$ and $b_{2}$ parameters for the samples sintered at $1020^{\circ} \mathrm{C}$ in oxygen (above $T_{p}$ ).

Taking in the account the results of the XRD we can assume, that the impurity phases $\left(\mathrm{Ca}_{3} \mathrm{Co}_{2} \mathrm{O}_{6},(\mathrm{Ca}, \mathrm{Co}) \mathrm{O}\right)$ in the samples $\mathrm{Ca}_{3} \mathrm{Co}_{3.8} \mathrm{O}_{9+\delta}, \mathrm{Ca}_{3} \mathrm{Co}_{4.2} \mathrm{O}_{9+\delta}$, which had been sintered in an oxygen atmosphere at $970^{\circ} \mathrm{C}$ and $1020^{\circ} \mathrm{C}$ present in amounts less than the sensitivity of the XRD 
method.

The apparent density of ceramics slightly depended on their composition and sintering temperature and varied within $2.53-2.86 \mathrm{~g} / \mathrm{cm}^{3}$ (Table 2); the highest value of $\rho_{\text {app }}$ was observed for the sample with an excess of cobalt oxide (calcium oxide deficiency) having $\mathrm{Ca}_{3} \mathrm{Co}_{4,2} \mathrm{O}_{9+\delta}$ composition, which had been annealed at $1020^{\circ} \mathrm{C}$ in oxygen.

Samples of the $\mathrm{Ca}_{3} \mathrm{Co}_{3.8} \mathrm{O}_{9+\delta}, \quad \mathrm{Ca}_{3} \mathrm{Co}_{4} \mathrm{O}_{9+\delta}$, and $\mathrm{Ca}_{3} \mathrm{Co}_{4.2} \mathrm{O}_{9+\delta}$ composition, sintered in a nitrogen atmosphere, were non-monophase, and, according to the XRD results, consisted of $\mathrm{CoO}, \mathrm{CaO}$, and $\mathrm{Ca}_{3} \mathrm{Co}_{4} \mathrm{O}_{9+\delta}$ phases, with cobalt oxide had being the predominant phase (Figure 2, lines 1-3, Table 3). After measuring of electrical conductivity (in air within the temperature range of 25$800^{\circ} \mathrm{C}$ ), the phase composition of the samples changed significantly: the most intense peaks corresponded to the phase of layered calcium cobaltate $\mathrm{Ca}_{3} \mathrm{Co}_{4} \mathrm{O}_{9+\delta}$ (Figure 2, lines 4-6, Table 3), formed by reaction:

$$
3 \mathrm{CaO}+4 \mathrm{CoO}+(1+0.5 \delta) \mathrm{O}_{2} \rightarrow \mathrm{Ca}_{3} \mathrm{Co}_{4} \mathrm{O}_{9+\delta} .
$$

Lattice constants of layered calcium cobaltate having both excess and deficiency of cobalt oxide in the samples sintered in nitrogen after their heat treatment in air similarly differed from the lattice constants of basic $\mathrm{Ca}_{3} \mathrm{Co}_{4} \mathrm{O}_{9+\delta}$ phase (Table 3): their $a, b_{1}$, and $b_{2}$ parameters were essentially smaller, but $c$ one was larger. On the diffraction patterns of these samples, in addition to the peaks of the main phase $\left(\mathrm{Ca}_{3} \mathrm{Co}_{4} \mathrm{O}_{9+\delta}\right)$, there were weakly expressed peaks of additional phases $(\mathrm{CaO}$ and $\mathrm{CoO})$, from which we can conclude that in this case too, the ceramic is a chemically and phase inhomogeneous composite material.

The apparent density of ceramics sintered at $920^{\circ}$, slightly depended on their composition and varied within $2.72-2.78 \mathrm{~g} / \mathrm{cm}^{3}$ (Table 3).

According to the EPMA results (Figure 3), chemical composition of the samples after their heat treatment at different conditions was correcponded, in the whole, to their nominal composition.

As can be seen from Figure 4, $a$, ceramics having $\mathrm{Ca}_{3} \mathrm{Co}_{4} \mathrm{O}_{9+\delta}$ composition, which had been sintered at $920^{\circ} \mathrm{C}$ in air contained only anisometric particles, the sizes of which in different directions varied within one to six micrometers (Table 4). Micrographs of ceramics of the same composition annealed at $970^{\circ} \mathrm{C}$ (Figure $4, b$ ) showed crystallites of two types - anisometric large particles for the main $\mathrm{Ca}_{3} \mathrm{Co}_{2} \mathrm{O}_{6}$ phase and small practically isometric inclusions of the $\mathrm{Co}_{3} \mathrm{O}_{4}$ phase.

Table 2. Apparent density ( $\left.\rho_{\text {app }}\right)$, phase composition and lattice constants $\left(a, b_{1}, b_{2}, c\right.$, $\beta$, ) of predominant phase in the ceramics based on the layered calcium cobaltate obtained in oxygen (O serie) at different temperatures $T$

\begin{tabular}{|c|c|c|c|c|c|c|c|c|c|}
\hline \multirow{2}{*}{ Composition } & \multirow{2}{*}{$T,{ }^{\circ} \mathrm{C}$} & \multirow{2}{*}{$\begin{array}{c}\rho_{\text {app }}, \\
\mathrm{g} / \mathrm{cm}^{3}\end{array}$} & \multicolumn{2}{|l|}{ Phase composition } & \multicolumn{5}{|c|}{ Lattice constants of predominant phase } \\
\hline & & & Expected & Real* & $a, \AA$ & $b_{1}, \AA$ & $b_{2}, \AA$ & $c, \AA$ & $\beta,^{\circ}$ \\
\hline $\mathrm{Ca}_{3} \mathrm{Co}_{3.8} \mathrm{O}_{9+\delta}$ & \multirow{3}{*}{970} & 2.73 & $\mathrm{Ca}_{3} \mathrm{Co}_{4} \mathrm{O}_{9+\delta}, \mathrm{Ca}_{3} \mathrm{Co}_{2} \mathrm{O}_{6}$ & \multirow{3}{*}{$\mathrm{Ca}_{3} \mathrm{Co}_{4} \mathrm{O}_{9+\delta}$} & $4.831(7)$ & $4.586(8)$ & $2.845(9)$ & $10.85(1)$ & $98.08(8)$ \\
\hline $\mathrm{Ca}_{3} \mathrm{Co}_{4} \mathrm{O}_{9+\delta}$ & & 2.69 & $\mathrm{Ca}_{3} \mathrm{Co}_{4} \mathrm{O}_{9+\delta}$ & & $4.826(7)$ & $4.554(8)$ & $2.823(9)$ & $10.83(1)$ & $98.10(8)$ \\
\hline $\mathrm{Ca}_{3} \mathrm{Co}_{4.2} \mathrm{O}_{9+\delta}$ & & 2.53 & $\mathrm{Ca}_{3} \mathrm{Co}_{4} \mathrm{O}_{9+\delta},(\mathrm{Co}, \mathrm{Ca}) \mathrm{O}$ & & $4.822(7)$ & $4.555(8)$ & $2.836(9)$ & $10.83(1)$ & 98.13(8) \\
\hline $\mathrm{Ca}_{3} \mathrm{Co}_{3.8} \mathrm{O}_{9+\delta}$ & \multirow{3}{*}{1020} & 2.73 & \multirow{3}{*}{$\mathrm{Ca}_{3} \mathrm{Co}_{4} \mathrm{O}_{9+\delta} *, \mathrm{Ca}_{3} \mathrm{Co}_{2} \mathrm{O}_{6},(\mathrm{Co}, \mathrm{Ca}) \mathrm{O}$} & \multirow{3}{*}{$\mathrm{Ca}_{3} \mathrm{Co}_{4} \mathrm{O}_{9+\delta}$} & $4.866(6)$ & $4.544(7)$ & $2.794(9)$ & $10.85(1)$ & $98.86(7)$ \\
\hline $\mathrm{Ca}_{3} \mathrm{Co}_{4} \mathrm{O}_{9+\delta}$ & & 2.62 & & & $4.843(7)$ & $4.575(8)$ & $2.821(9)$ & $10.87(1)$ & $98.45(8)$ \\
\hline $\mathrm{Ca}_{3} \mathrm{Co}_{4.2} \mathrm{O}_{9+\delta}$ & & 2.86 & & & $4.858(7)$ & $4.537(8)$ & $2.799(9)$ & $10.85(1)$ & 98.83(8) \\
\hline
\end{tabular}

*According to the X-ray data

\#According to [24], at $1020^{\circ} \mathrm{C}$ in oxygen this phase is thermodynamically unstable, but can form at slow cooling of the sample to the room temperature due to the peritectoid reaction of $\mathrm{Ca}_{3} \mathrm{Co}_{2} \mathrm{O}_{6}+(\mathrm{Co}, \mathrm{Ca}) \mathrm{O} \rightarrow \mathrm{Ca}_{3} \mathrm{Co}_{4} \mathrm{O}_{9+\delta}$.
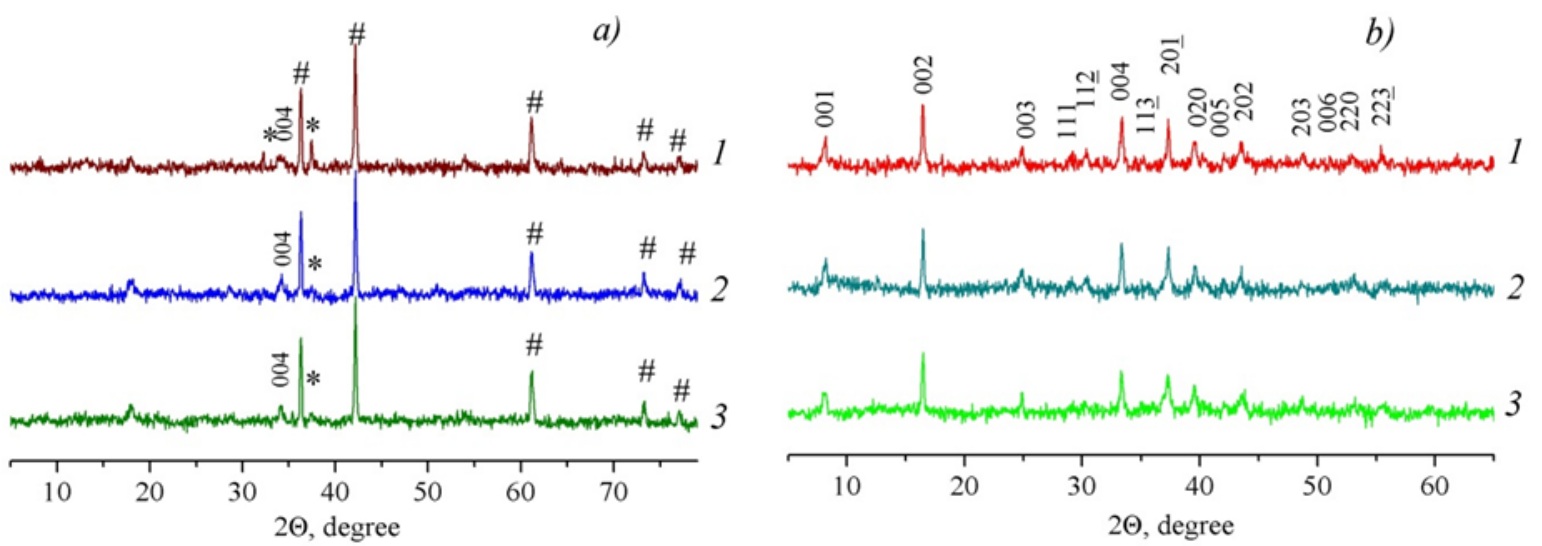

Figure 2. X-ray powder diffractograms (CuK $\alpha_{\alpha}$-radiation) of $\mathrm{Ca}_{3} \mathrm{Co}_{4} \mathrm{O}_{9+\delta}(1), \mathrm{Ca}_{3} \mathrm{Co}_{3.8} \mathrm{O}_{9+\delta}$ (2), and $\mathrm{Ca}_{3} \mathrm{Co}_{4.2} \mathrm{O}_{9+\delta}$ (3) samples, sintered in nitrogen at $920^{\circ} \mathrm{C}$ before $(a)$ and after $(b)$ measurements of their electrotransport properties in air within $25-800^{\circ} \mathrm{C}$. The $\mathrm{Miller}$ indices of $\mathrm{Ca}_{3} \mathrm{Co}_{4} \mathrm{O}_{9+\delta}$ phase are indicated. Symbols *and \# depict the reflexes of $\mathrm{CaO}$ and $\mathrm{CoO}$ phases respectively 
Table 3. Apparent density ( $\left.\rho_{\text {app }}\right)$, phase composition and lattice constants $\left(a, b_{1}, b_{2}, c\right.$, $\beta$, ) of predominant phase in the ceramics based on the layered calcium cobaltate obtained in nitrogen $\left(\mathrm{N}\right.$ serie) at $920^{\circ} \mathrm{C}$ before (nitrogen) and after (nitrogen+air) measurements of their electrotransport properties in air within $25-800^{\circ} \mathrm{C}$

\begin{tabular}{|c|c|c|c|c|c|c|c|c|c|c|}
\hline \multirow{2}{*}{ Composition } & \multirow{2}{*}{ Prehistory } & \multirow{2}{*}{$\begin{array}{c}\rho_{\mathrm{app}}, \\
\mathrm{g} / \mathrm{cm}^{3}\end{array}$} & \multicolumn{2}{|c|}{ Phase composition } & \multirow{2}{*}{$\begin{array}{c}\text { Predominant } \\
\text { phase }\end{array}$} & \multicolumn{5}{|c|}{ Lattice constants of predominant phase } \\
\hline & & & Expected & Real* & & $a, \AA$ & $b_{1}, \AA$ & $b_{2}, \AA$ & $c, \AA$ & $\beta,^{\circ}$ \\
\hline $\mathrm{Ca}_{3} \mathrm{Co}_{3.8} \mathrm{O}_{9+\delta}$ & \multirow{3}{*}{ Nitrogen } & 2.76 & \multirow{3}{*}{$\mathrm{CaO}, \mathrm{CoO}$} & \multirow{3}{*}{$\begin{array}{l}\mathrm{CaO}, \mathrm{CoO} \\
\mathrm{Ca}_{3} \mathrm{Co}_{4} \mathrm{O}_{9+\delta}\end{array}$} & \multirow{3}{*}{$\mathrm{CoO}$} & $4.278(3)$ & - & - & - & - \\
\hline $\mathrm{Ca}_{3} \mathrm{Co}_{4} \mathrm{O}_{9+\delta}$ & & 2.75 & & & & $4.281(3)$ & - & - & - & - \\
\hline $\mathrm{Ca}_{3} \mathrm{Co}_{4.2} \mathrm{O}_{9+\delta}$ & & 2.72 & & & & $4.282(3)$ & - & - & - & - \\
\hline $\mathrm{Ca}_{3} \mathrm{Co}_{3.8} \mathrm{O}_{9+\delta}$ & \multirow{3}{*}{ Nitrogen+air } & 2.78 & $\mathrm{Ca}_{3} \mathrm{Co}_{4} \mathrm{O}_{9+\delta}$ & \multirow{3}{*}{$\mathrm{Ca}_{3} \mathrm{Co}_{4} \mathrm{O}_{9+\delta}$} & \multirow{3}{*}{$\mathrm{Ca}_{3} \mathrm{Co}_{4} \mathrm{O}_{9+\delta}$} & $4.811(7)$ & $4.544(9)$ & $2.824(9)$ & 10.91(1) & $97.91(9)$ \\
\hline $\mathrm{Ca}_{3} \mathrm{Co}_{4} \mathrm{O}_{9+\delta}$ & & 2.77 & $\mathrm{Ca}_{3} \mathrm{Co}_{4} \mathrm{O}_{9+\delta}$ & & & $4.838(6)$ & $4.586(7)$ & $2.843(9)$ & $10.84(1)$ & 98.33(7) \\
\hline $\mathrm{Ca}_{3} \mathrm{Co}_{4.2} \mathrm{O}_{9+\delta}$ & & 2.75 & $\mathrm{Ca}_{3} \mathrm{Co}_{4} \mathrm{O}_{9+\delta}$ & & & 4.804(9) & 4.556(9) & $2.820(9)$ & 10.91(1) & 98.08(9) \\
\hline
\end{tabular}

*According to the X-ray data

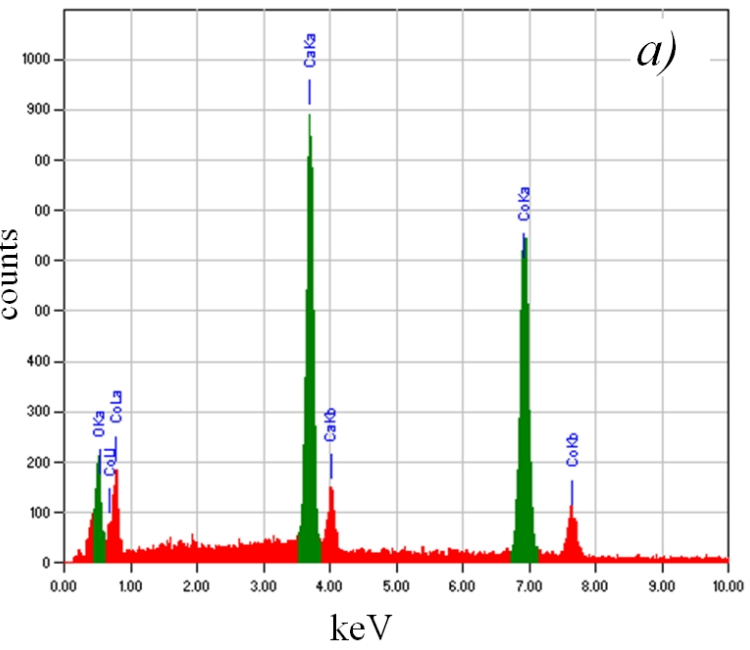

a)

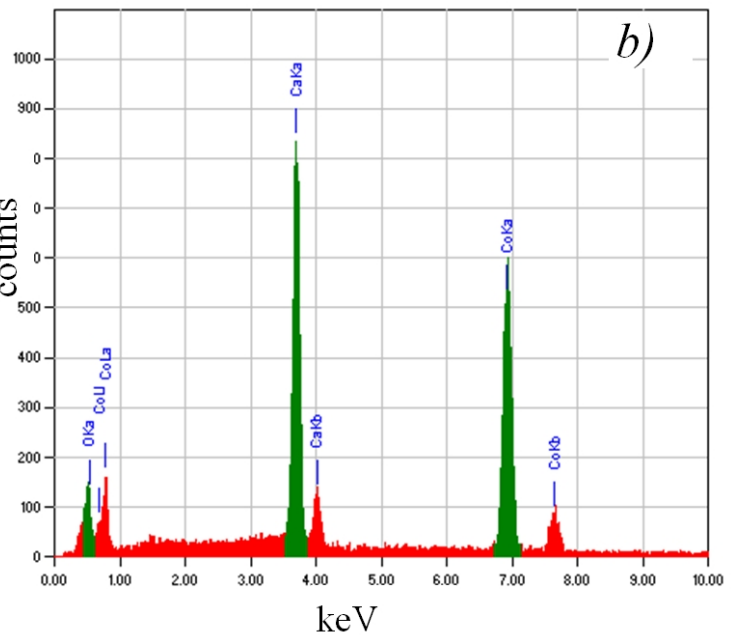

b)

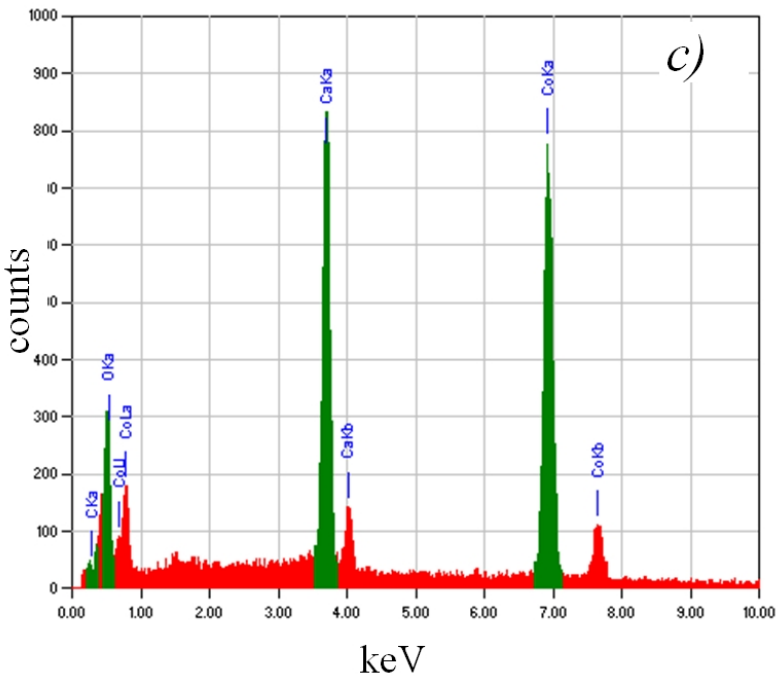

c)

Figure 3. EPMA graphs for the samples $\mathrm{Ca}_{3} \mathrm{Co}_{3.8} \mathrm{O}_{9+\delta}(a), \mathrm{Ca}_{3} \mathrm{Co}_{4} \mathrm{O}_{9+\delta}(b)$, and $\mathrm{Ca}_{3} \mathrm{Co}_{4.2} \mathrm{O}_{9+\delta}(c)$, sintered in air at $920^{\circ} \mathrm{C}$

According to the results of EMPA of the cleaved surfaces, all phases are not individual compounds, but substitution solid solutions (Table 4). The fact that the spinel phase is a solid solution of calcium oxide in cobalt oxide (II, III) $\left(\mathrm{Co}_{0.9} \mathrm{Ca}_{0.1}\right)_{3} \mathrm{O}_{4}$ is consistent with the phase diagram of the $\mathrm{CaO}-\mathrm{CoO}$ quasibinary system [24]. The excess of cobalt in layered calcium cobaltate and quasi-one-dimensional calcium cobaltite is most likely due to the partial segregation of cobalt oxide between the volume and surface of the ceramic grains. In other words, 
the ceramics we obtained is not only non-monophase, but also chemically inhomogeneous.

The crystallites of ceramics of $\mathrm{Ca}_{3} \mathrm{Co}_{4} \mathrm{O}_{9+\delta}$ composition, which had been sintered in oxygen at a temperature of $1020^{\circ} \mathrm{C}$ were larger and more anisometric (Figure 4, c) than for ceramics of the same composition sintered in air at $920^{\circ} \mathrm{C}$, and had an average particle size of about $5.8 \times 2.7 \times 1.0 \mu \mathrm{m}$ (Table 4). According to the EMPA results, the particles were enriched in cobalt oxide (Table 4), which, as in the previous case, is most likely explained by its partial segregation between the volume and surface of the ceramic grains.

Micrographs of ceramics annealed at $920^{\circ} \mathrm{C}$ in a nitrogen atmosphere showed crystallites of two types: anisometric large particles, which are heterogeneous aggregates consisting of $\mathrm{Ca}_{3} \mathrm{Co}_{4} \mathrm{O}_{9+\delta}, \mathrm{CaO}$, and $\mathrm{CoO}$ phases, and small practically isometric inclusions of the $\mathrm{CoO}$ phase (Figure $4, d$ ). After additional heat treatment in air (measurements of electrical conductivity), as a result of a change in the phase composition of the ceramic, a noticeable change in its microstructure was occurred, consisting in a change in the shape and size of the ceramic grains (Figure 4,e). According to the EMPA results of the cleaved surfaces, all phases are not individual compounds, but substitution solid solutions, and, as in the case of ceramics sintered in air and in oxygen, phase crystallites based on layered calcium cobaltate contained an excess amount compared to stoichiometric cobalt oxide (Table 4).

As can be seen from the data given in the Figure 5 (upper block), the materials based on the layered calcium cobaltate, which had been sintered in air, were $p$-type $(S>0)$ semiconductors $(\partial \sigma / \partial T>0)$, while $\mathrm{Ca}_{3} \mathrm{Co}_{4.2} \mathrm{O}_{9+\delta}$ ceramics sintered at $970^{\circ} \mathrm{C}$ was characterized by the highest electrical conductivity, and the highest values of the coefficient of thermo-EMF was observed for ceramics $\mathrm{Ca}_{3} \mathrm{Co}_{4.2} \mathrm{O}_{9+\delta}$ sintered both at $920^{\circ} \mathrm{C}$ and at $970^{\circ} \mathrm{C}$ (Table 5), which is most likely due to its phase heterogeneity (see Figure, 1, $a$, Table. 1). The values of electrical conductivity and coefficient of thermo-EMF of ceramics, in the whole, were increased at increasing of the cobalt oxide content in the samples (Table 5). The values of the apparent activation energy of electrical conductivity of the samples of A serie varied within $0.069-0.081 \mathrm{eV}$, which is typical for ceramics based on the layered calcium cobaltate $[12,14,16]$ (excluding the samples having $\mathrm{Ca}_{3} \mathrm{Co}_{3.8} \mathrm{O}_{9+\delta}, \mathrm{Ca}_{3} \mathrm{Co}_{4} \mathrm{O}_{9+\delta}$ composition, which had been sintered at $970^{\circ} \mathrm{C}$, whose $E_{A}$ values were equal to 0.274 and $0.125 \mathrm{eV}$ respectively and were abnormally high, which was probably due to the peculiarities of their microstructure).

The power factor values of sintered in air ceramics had been increased at temperature increasing, and for sample having $\mathrm{Ca}_{3} \mathrm{Co}_{4.2} \mathrm{O}_{9+\delta}$ composition, containing an excess of cobalt oxide, were significantly higher than for the basic monophase layered calcium cobaltate $\mathrm{Ca}_{3} \mathrm{Co}_{4} \mathrm{O}_{9+\delta}$ (Figure 5, upper block, Table 5). So, for $\mathrm{Ca}_{3} \mathrm{Co}_{4.2} \mathrm{O}_{9+\delta}$ ceramics sintered at $920^{\circ} \mathrm{C}$ and $970^{\circ} \mathrm{C}, P$ values at $800^{\circ} \mathrm{C}$ were equal to 255 and $273 \mu \mathrm{W} /\left(\mathrm{m} \cdot \mathrm{K}^{2}\right)$, respectively, which was 2.1 and 2.3 times higher than for the basic layered calcium cobaltate $\mathrm{Ca}_{3} \mathrm{Co}_{4} \mathrm{O}_{9+\delta}$ at the same temperature.

Samples which were sintered in oxygen were also $p$-type $(S>0)$ semiconductors $(\partial \sigma / \partial T>0)$ (Figure 5, middle block), although their electrical conductivity values at temperature gaining increased less significant than for the samples, sintered in air.

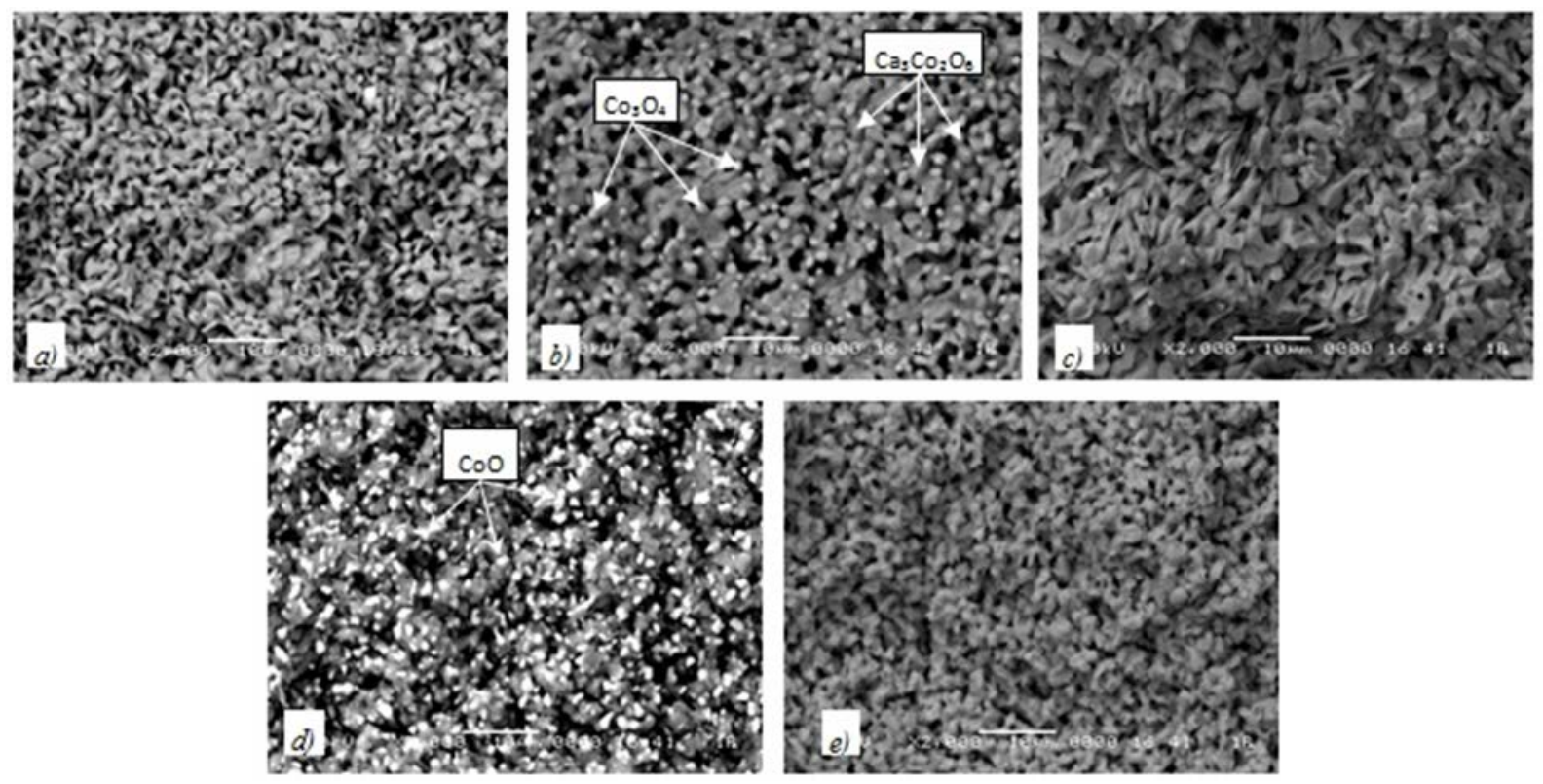

Figure 4. Electron micrographs of surface of $\mathrm{Ca}_{3} \mathrm{Co}_{4} \mathrm{O}_{9+\delta}$ ceramics, annealed in air at $920^{\circ} \mathrm{C}(a)$ and $970^{\circ} \mathrm{C}(b)$, in oxygen at $1020^{\circ} \mathrm{C}(c)$, in nitrogen at $920^{\circ} \mathrm{C}$ before $(d)$ and after $(e)$ measurements of its electrotransport properties in air within $25-800^{\circ} \mathrm{C}$ 
Table 4. The results of analysis of surface of cleavages of ceramics based on the layered calcium cobaltate sintered at different conditions (T, atmosphere) according EM and EMPA

\begin{tabular}{|c|c|c|c|c|c|c|}
\hline \multirow{3}{*}{$\begin{array}{c}\text { Sintering conditions } \\
\text { Phase } \\
\end{array}$} & \multicolumn{3}{|c|}{ Air } & \multirow{3}{*}{$\begin{array}{c}\text { Oxygen } \\
1020^{\circ} \mathrm{C} \\
\mathrm{Ca}_{3} \mathrm{Co}_{4} \mathrm{O}_{9+\delta} \\
\end{array}$} & Nitrogen & Nitrogen (+air) \\
\hline & \multirow{2}{*}{$\begin{array}{c}920^{\circ} \mathrm{C} \\
\mathrm{Ca}_{3} \mathrm{Co}_{4} \mathrm{O}_{9+\delta}\end{array}$} & \multicolumn{2}{|c|}{$970^{\circ} \mathrm{C}$} & & \multicolumn{2}{|c|}{$920^{\circ} \mathrm{C}\left(+25-800^{\circ} \mathrm{C}\right)$} \\
\hline & & $\mathrm{Ca}_{3} \mathrm{Co}_{2} \mathrm{O}_{6}$ & $\mathrm{Co}_{3} \mathrm{O}_{4}$ & & $\mathrm{CoO}$ & $\mathrm{Ca}_{3} \mathrm{Co}_{4} \mathrm{O}_{9+\delta}$ \\
\hline$x_{\mathrm{Ca}}$, at. $\%$ & 36.35 & 48.65 & 9.98 & 33.35 & 15.01 & 32.62 \\
\hline$x_{\mathrm{Co}}$, at. $\%$ & 63.65 & 51.35 & 90.02 & 66.65 & 84.99 & 67.38 \\
\hline$x_{\mathrm{CaO}}$, wt. $\%$ & 29.94 & 41.48 & 7.66 & 27.24 & 11.68 & 26.60 \\
\hline$x_{\mathrm{CoO}}$, wt. $\%$ & 70.06 & 58.52 & 92.34 & 72.76 & 88.32 & 73.40 \\
\hline Phase composition & $\left(\mathrm{Ca}_{0.85} \mathrm{Co}_{0.15}\right)_{3} \mathrm{Co}_{4} \mathrm{O}_{9+\delta}$ & $\left(\mathrm{Ca}_{0.81} \mathrm{Co}_{0.19}\right)_{3} \mathrm{Co}_{2} \mathrm{O}_{6}$ & $\left(\mathrm{Co}_{0.9} \mathrm{Ca}_{0.1}\right)_{3} \mathrm{O}_{4}$ & $\left(\mathrm{Ca}_{0.82} \mathrm{Co}_{0.18}\right)_{3} \mathrm{Co}_{4} \mathrm{O}_{9+\delta}$ & $\mathrm{Co}_{0.8} \mathrm{Ca}_{0.2} \mathrm{O}$ & $\left(\mathrm{Ca}_{0.91} \mathrm{Co}_{0.09}\right)_{3} \mathrm{Co}_{4} \mathrm{O}_{9+\delta}$ \\
\hline $\begin{array}{l}\text { Average crystallite size } \\
\text { (given in the } x \times y \times z \\
\text { directions), } \mu \mathrm{m}\end{array}$ & $2.2 \times 1.7 \times 0.5$ & $5.2 \times 3.4 \times 1.7$ & $1.6 \times 1.6 \times 1.6$ & $5.8 \times 2.7 \times 1.0$ & $1.7 \times 1.7 \times 1.7$ & $2.3 \times 1.8 \times 1.7$ \\
\hline
\end{tabular}



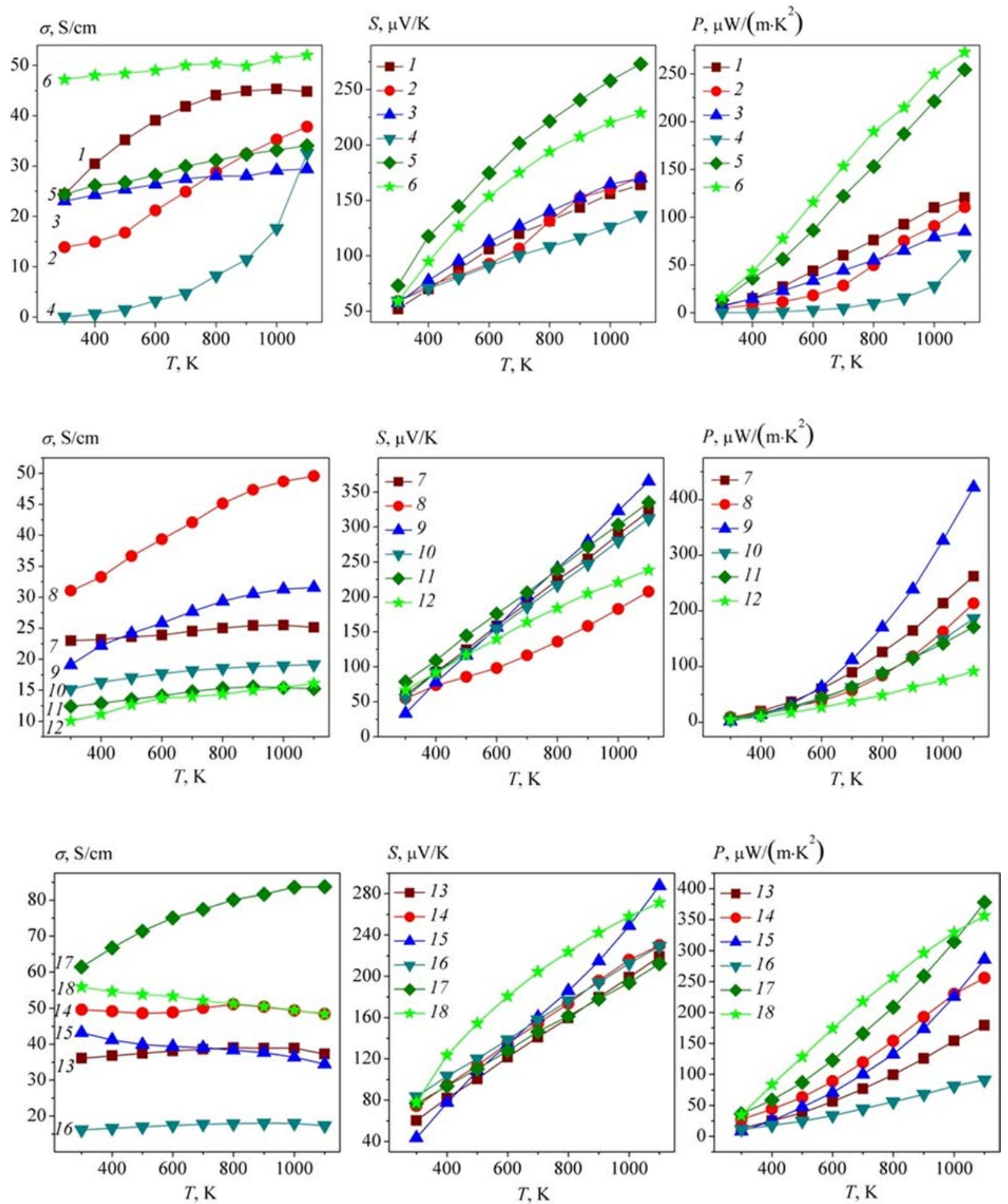

Figure 5. Temperature dependences of electrical conductivity $(\sigma)$, thermo-EMF coefficient $(S)$, and power factor $(P)$ of $\mathrm{Ca}_{3} \mathrm{Co}_{4} \mathrm{O}_{9+\delta}(1,2,7,8,13,14)$, $\mathrm{Ca}_{3} \mathrm{Co}_{3.8} \mathrm{O}_{9+\delta}(3,4,9,10,15,16)$, and $\mathrm{Ca}_{3} \mathrm{Co}_{4.2} \mathrm{O}_{9+\delta}(5,6,11,12,17,18)$ ceramics, annealed in air $(1-6)$, oxygen $(7-12)$ and nitrogen $(13-18)$ at $890^{\circ} \mathrm{C}$ (13), $920^{\circ} \mathrm{C}(1,3,5,15,17), 970^{\circ} \mathrm{C}(2,4,6,7,9,11,14,16,18)$, and $1020^{\circ} \mathrm{C}(8,10,12)$ 
Table 5. Values of apparent density $\left(\rho_{\text {app }}\right)$, electrical conductivity $\left(\sigma_{800}\right)$, thermo-EMF coefficient $\left(S_{800}\right)$, apparent activation energy of electrical conductivity $\left(E_{A}\right)$, and power factor $\left(P_{800}\right)$ of ceramics, based on the layered calcium cobaltate, sintered at different conditions $(T$, atmosphere)

\begin{tabular}{|c|c|c|c|c|c|c|c|}
\hline \multicolumn{2}{|c|}{ Sintering conditions } & \multirow{2}{*}{ Composition } & \multirow{2}{*}{$\rho_{\text {app }}, \mathrm{g} / \mathrm{cm}^{3}$} & \multirow{2}{*}{$\sigma_{800}, \mathrm{~S} / \mathrm{cm}$} & \multirow{2}{*}{$S_{800}, \mu \mathrm{V} / \mathrm{K}$} & \multirow{2}{*}{$E_{A}, \mathrm{eV}$} & \multirow{2}{*}{$P_{800}, \mu \mathrm{W} /\left(\mathrm{m} \cdot \mathrm{K}^{2}\right)$} \\
\hline Atmosphere & $T,{ }^{\circ} \mathrm{C}$ & & & & & & \\
\hline \multirow{6}{*}{ Air } & \multirow{3}{*}{$920^{\circ} \mathrm{C}$} & $\mathrm{Ca}_{3} \mathrm{Co}_{3.8} \mathrm{O}_{9+\delta}$ & 2.87 & 29.4 & 170 & 0.069 & 85.1 \\
\hline & & $\mathrm{Ca}_{3} \mathrm{Co}_{4} \mathrm{O}_{9+\delta}$ & 2.77 & 44.8 & 164 & 0.081 & 121 \\
\hline & & $\mathrm{Ca}_{3} \mathrm{Co}_{4.2} \mathrm{O}_{9+\delta}$ & 2.72 & 34.1 & 273 & 0.076 & 255 \\
\hline & \multirow{3}{*}{$970^{\circ} \mathrm{C}$} & $\mathrm{Ca}_{3} \mathrm{Co}_{3.8} \mathrm{O}_{9+\delta}$ & 3.20 & 32.6 & 137 & 0.274 & 60.8 \\
\hline & & $\mathrm{Ca}_{3} \mathrm{Co}_{4} \mathrm{O}_{9+\delta}$ & 3.01 & 37.9 & 171 & 0.125 & 111 \\
\hline & & $\mathrm{Ca}_{3} \mathrm{Co}_{4.2} \mathrm{O}_{9+\delta}$ & 3.11 & 52.0 & 229 & 0.064 & 273 \\
\hline \multirow{6}{*}{ Oxygen } & \multirow{3}{*}{$970^{\circ} \mathrm{C}$} & $\mathrm{Ca}_{3} \mathrm{Co}_{3.8} \mathrm{O}_{9+\delta}$ & 2.73 & 31.6 & 366 & 0.080 & 422 \\
\hline & & $\mathrm{Ca}_{3} \mathrm{Co}_{4} \mathrm{O}_{9+\delta}$ & 2.69 & 25.2 & 323 & 0.065 & 262 \\
\hline & & $\mathrm{Ca}_{3} \mathrm{Co}_{4.2} \mathrm{O}_{9+\delta}$ & 2.53 & 15.2 & 335 & 0.068 & 171 \\
\hline & \multirow{3}{*}{$1020^{\circ} \mathrm{C}$} & $\mathrm{Ca}_{3} \mathrm{Co}_{3.8} \mathrm{O}_{9+\delta}$ & 2.73 & 19.2 & 312 & 0.063 & 187 \\
\hline & & $\mathrm{Ca}_{3} \mathrm{Co}_{4} \mathrm{O}_{9+\delta}$ & 2.62 & 49.5 & 208 & 0.082 & 214 \\
\hline & & $\mathrm{Ca}_{3} \mathrm{Co}_{4,2} \mathrm{O}_{9+\delta}$ & 2.86 & 16.1 & 239 & 0.070 & 91.7 \\
\hline \multirow{7}{*}{ Nitrogen* } & $890^{\circ} \mathrm{C}$ & $\mathrm{Ca}_{3} \mathrm{Co}_{4} \mathrm{O}_{9+\delta}$ & 2.63 & 37.3 & 219 & 0.060 & 179 \\
\hline & \multirow{3}{*}{$920^{\circ} \mathrm{C}$} & $\mathrm{Ca}_{3} \mathrm{Co}_{3.8} \mathrm{O}_{9+\delta}$ & 2.76 & 34.5 & 288 & 0.050 & 286 \\
\hline & & $\mathrm{Ca}_{3} \mathrm{Co}_{4} \mathrm{O}_{9+\delta}$ & 2.75 & 50.7 & - & 0.062 & - \\
\hline & & $\mathrm{Ca}_{3} \mathrm{Co}_{4.2} \mathrm{O}_{9+\delta}$ & 2.76 & 83.8 & 212 & 0.072 & 378 \\
\hline & \multirow{3}{*}{$970^{\circ} \mathrm{C}$} & $\mathrm{Ca}_{3} \mathrm{Co}_{3.8} \mathrm{O}_{9+\delta}$ & 2.95 & 17.3 & 229 & 0.064 & 91.1 \\
\hline & & $\mathrm{Ca}_{3} \mathrm{Co}_{4} \mathrm{O}_{9+\delta}$ & 2.73 & 48.4 & 230 & 0.059 & 256 \\
\hline & & $\mathrm{Ca}_{3} \mathrm{Co}_{4.2} \mathrm{O}_{9+\delta}$ & 2.85 & 48.4 & 271 & 0.051 & 356 \\
\hline
\end{tabular}

*All the samples sintered in nitrogen atmosphere, were light-brown in color, but after measurements of their electrical conductivity or thermo-EMF in air their color was changing into black, obviously, due to their oxidation and change in phase composition (from mixture of CoO and CaO into ceramics based on the $\mathrm{Ca}_{3} \mathrm{Co}_{4} \mathrm{O}_{9+\delta}$ phase)

The highest electrical conductivity was demonstrated by ceramics having $\mathrm{Ca}_{3} \mathrm{Co}_{4} \mathrm{O}_{9+\delta}$ composition which had been sintered at $1020^{\circ} \mathrm{C}$, and the highest value of the thermo-EMF coefficient was observed for ceramics of $\mathrm{Ca}_{3} \mathrm{Co}_{3.8} \mathrm{O}_{9+\delta}$ composition which had been sintered at $970^{\circ} \mathrm{C}$ (Table 5). It is interesting to note that the values of the thermo-EMF coefficient of ceramics containing an excess of both calcium oxide $\left(\mathrm{Ca}_{3} \mathrm{Co}_{3.8} \mathrm{O}_{9+\delta}\right)$ and cobalt oxide $\left(\mathrm{Ca}_{3} \mathrm{Co}_{4.2} \mathrm{O}_{9+\delta}\right)$ were higher than for the basic $\mathrm{Ca}_{3} \mathrm{Co}_{4} \mathrm{O}_{9+\delta}$ phase with stoichiometric relation of cations (Table 5). Thus, the creation of phase and chemical heterogeneity in ceramics based on the layered calcium cobaltate leads to an increase in its thermo-EMF coefficient.

The values of the apparent activation energy of electrical conductivity of the samples of $\mathrm{O}$ serie varied within 0.065 $0.082 \mathrm{eV}$, which is typical for ceramics based on the layered calcium cobaltate [12, 14, 16], and slightly depended on the cationic compostiton of the samples and temperature of their sintering.

The values of the power factor of oxygen-sintered ceramics increased at temperature increasing and were the highest for ceramics of $\mathrm{Ca}_{3} \mathrm{Co}_{3.8} \mathrm{O}_{9+\delta}$ composition which had been sintered at $970^{\circ} \mathrm{C}$, and its $P$ value at a temperature of $800^{\circ} \mathrm{C}$ was equal to $420 \mu \mathrm{W} /\left(\mathrm{m} \cdot \mathrm{K}^{2}\right)$, which is 3.5 times higher than for $\mathrm{Ca}_{3} \mathrm{Co}_{4} \mathrm{O}_{9+\delta}$ ceramics sintered in air at

\section{$920^{\circ} \mathrm{C}$ (Table 5).}

The materials sintered in nitrogen were p-type conductors $(S>0)$, the conductivity of which was weakly dependent on the temperature or had a metallic character $(\partial \sigma / \partial T<0)$ (except for a sample of $\mathrm{Ca}_{3} \mathrm{Co}_{4.2} \mathrm{O}_{9+\delta}$ composition, which conductivity had a semiconducting character $(\partial \sigma / \partial T>0)$ and showed the highest values in this series) (Figure 5, lower block, Table 5). Interestingly, that increasing of sintering temperature of ceramics resulted in decreasing of their electrical conductivity values, probably, due to the more pronouncied of phase heterogeneity as well as due to the lowering of cobalt oxidation degree in them leading to the decreasing of concentration of main charge carriers - "holes".

The values of the thermo-EMF coefficient of ceramics sintered in nitrogen increased with increasing temperature and were close each other, excluding sample $\mathrm{Ca}_{3} \mathrm{Co}_{3.8} \mathrm{O}_{9+\delta}$ sintered at $920^{\circ} \mathrm{C}$ and sample $\mathrm{Ca}_{3} \mathrm{Co}_{4.2} \mathrm{O}_{9+\delta}$ sintered at $970^{\circ} \mathrm{C}$, which thermo-EMF coefficient were approximately 25\% higher (Table 5). The maximal values of thermo-EMF coefficient (like for the samples which were sintered in oxygen) was observed for chemically inhomogeneous samples, which contained an excess of calcium oxide $\left(\mathrm{Ca}_{3} \mathrm{Co}_{3.8} \mathrm{O}_{9+\delta}\right)$ or cobalt oxide $\left(\mathrm{Ca}_{3} \mathrm{Co}_{4.2} \mathrm{O}_{9+\delta}\right)$ (Table 5), which is another confirmation of the fact that inhomogeneity of layered calcium cobaltate improve its 
thermoelectric properties.

The values of the apparent activation energy of electrical conductivity of the samples of $\mathrm{N}$ serie varied within 0.050 $0.072 \mathrm{eV}$, which is typical for ceramics based on the layered calcium cobaltate $[12,14,16]$, slightly depended on the cationic compostiton of the samples and temperature of their sintering, and were less than for the samples which had been sintered in air or in oxygen.

The power factor values of ceramics sintered in nitrogen increased at temperature increasing (Figure 5, lower block), while the character of the $P=f(T)$ dependences of the samples was determined mainly by the character of the temperature dependences of their thermo-EMF coefficient $(S=f(T)$ ). As can be seen (Figure 5, Table 5), the highest values of the power factor at $1100 \mathrm{~K}$ had the samples containing excess of cobalt oxide $-\mathrm{Ca}_{3} \mathrm{Co}_{4.2} \mathrm{O}_{9+\delta}$, sintered at temperatures of $920^{\circ} \mathrm{C}\left(P_{800}=378 \mu \mathrm{W} /\left(\mathrm{m} \cdot \mathrm{K}^{2}\right)\right.$ and $970^{\circ} \mathrm{C}\left(P_{800}=356 \mu \mathrm{W} /\left(\mathrm{m} \cdot \mathrm{K}^{2}\right)\right)$, which is 3.1 and 2.9 times higher than for the basic monophase ceramics of layered calcium cobaltate $\mathrm{Ca}_{3} \mathrm{Co}_{4} \mathrm{O}_{9+\delta}$.

Comparing the results obtained for the ceramics having of various cationic composition and sintered at different conditions we can make some conclusions:

a) electrical conductivity of the samples was increased after they had been sintered both in oxidizing (oxygen) and reducing (nitrogen) atmospheres; in the first case it is due to the increasing of average oxidation degree of cobalt ions in their crystal structure leading to the increasing of concentration of main charge carriers "holes", in the second case the heat post-treatment in air atmosphere of samples sintered in nitrogen (during measurements of their electrical conductivity) led to their oxidation and, consequently, to increasing of charge carriers concentration;

b) the values of apparent activation energy of electrical conductivity of the samples, in the whole, were close each other, and varied within $0.05-0.08 \mathrm{eV}$; so, mechanism of electrical conductivity in all the samples studied is the same, and charge transfer in them is took place through the $\mathrm{Ca}_{3} \mathrm{Co}_{4} \mathrm{O}_{9+\delta}$ phase (both in homogeneous and heterogeneous ceramics);

c) values of thermo-EMF coefficient are larger for the samples containing an excess both cobalt oxide and calcium oxide, which was more pronounced for the samples sintered in oxygen and nitrogen; thus, creation in the ceramics based on the layered calcium cobaltate of phase and chemical inhomogeneity essentially improves its thermoelectric (functional) properties.

\section{Conclusions}

Ceramic samples of $\mathrm{Ca}_{3} \mathrm{Co}_{x} \mathrm{O}_{9+\delta}(x=3.8,4.0$, and 4.2) composition were prepared using citrate method and then sintered in different atmospheres (oxygen, air, nitrogen) below and above temperature of peritectoid decomposition of layered calcium cobaltate $\mathrm{Ca}_{3} \mathrm{Co}_{4} \mathrm{O}_{9+\delta}$. Their crystal structure, microstrucrture, electrical conductivity, thermo-EMF coefficient, and power factor in air within $25-800^{\circ} \mathrm{C}$ were investigated. It had been found that increase of cobalt oxide content in the samples led to the increasing of their electrical conductivity, the creation of phase inhomogeneity in ceramics (by both varying of their cationic composition and by heat treatment at temperatures above temperature of peritectoid decomposition) improves its thermo-EMF coefficient, which, in the whole, improves thermoelectric properties of ceramics based on the layered calcium cobaltate $\mathrm{Ca}_{3} \mathrm{Co}_{4} \mathrm{O}_{9+\delta}$. So, power factor values of phase and chemically inhomogeneous ceramics $\mathrm{Ca}_{3} \mathrm{Co}_{4.2} \mathrm{O}_{9+\delta}$, sintered in air below and above temperature of peritectoid decomposition of layered calcium cobaltate, at $800^{\circ} \mathrm{C}$ were equal 255 and $273 \mu \mathrm{W} /\left(\mathrm{m} \cdot \mathrm{K}^{2}\right)$ respectively, which was 2.1 and 2.4 times larger than for the $\mathrm{Ca}_{3} \mathrm{Co}_{4} \mathrm{O}_{9+\delta}$. It had been also found that sintering of phase inhomogeneous ceramics both in oxidizing or reducing atmospheres led to the improving of its functional properties. So, power factor values of $\mathrm{Ca}_{3} \mathrm{Co}_{3.8} \mathrm{O}_{9+\delta}$ (sintered in oxygen at $970^{\circ} \mathrm{C}$ ) and $\mathrm{Ca}_{3} \mathrm{Co}_{4.2} \mathrm{O}_{9+\delta}$ (sintered in nitrogen at $920^{\circ} \mathrm{C}$ ) at $800^{\circ} \mathrm{C}$ were equal 422 and 378 $\mu \mathrm{W} /\left(\mathrm{m} \cdot \mathrm{K}^{2}\right)$ respectively, which was 3.5 and 3.1 times larger than for the $\mathrm{Ca}_{3} \mathrm{Co}_{4} \mathrm{O}_{9+\delta}$.

\section{Abbreviations}

EMF electromotive force

XRD x-ray diffraction analysis

EDX energy-dispersive $\mathrm{x}$-ray analysis

EM electron microscopy

EMPA electronic micro probe analysis

\section{Acknowledgements}

This work was carried out in the frame of SPSI «Physical materials science, new materials and technologies» (subprogram «Materials science and materials technologies», task 1.55).

\section{REFERENCES}

[1] D.M. Rowe. Handbook of Thermoelectrics, Boca Raton, CRC Press, 1995.

[2] K. Koumoto, I. Terasaki, N. Murayama (eds.). Oxide Thermoelectrics. Research Signpost, Trivandrum, India, Research Signpost, 2002.

[3] J.W. Fergus, Oxide materials for high temperature thermoelectric energy conversion, J. Eur. Ceram. Soc., Vol. 32, 525-540, 2012. 
[4] Y.F. Zhang, J.X. Zhang, Q.M. Lu, Q.Y. Zhang, Synthesis and characterization of $\mathrm{Ca}_{3} \mathrm{Co}_{4} \mathrm{O}_{9}$ nanoparticles by citrate sol-gel method // Mater. Lett., Vol. 60, 2443-2446, 2006.

[5] A.K. Królicka, M. Piersa, A. Mirowska, M. Michalska, Effect of sol-gel and solid-state synthesis techniques on structural, morphological and thermoelectric performance of $\mathrm{Ca}_{3} \mathrm{Co}_{4} \mathrm{O}_{9} / /$ Ceram. Int., Vol. 44, No. 12, 13736-13743, 2018.

[6] S. Katsuyama, Y. Takiguchi, M. Ito. Synthesis of $\mathrm{Ca}_{3} \mathrm{Co}_{4} \mathrm{O}_{9+\delta}$ ceramics by polymerized complex method and hydrothermal hot-pressing processes and the investigation of its thermoelectric properties // J. Mater. Sci., Vol. 43, 3553-3559, 2008.

[7] J.G. Noudem, M. Prevel, A. Veres, D. Chateigner, Thermoelectric $\mathrm{Ca}_{3} \mathrm{Co}_{4} \mathrm{O}_{9}$ Ceramics Consolidated by Spark Plasma Sintering // J. Electroceram. Vol. 22, 91-97, 2009.

[8] Y. Liu, Y. Lin, Z. Shi, C.-W. Nan, Z. Shen, Preparation of $\mathrm{Ca}_{3} \mathrm{Co}_{4} \mathrm{O}_{9}$ and Improvement of its Thermoelectric Properties by Spark Plasma Sintering // J. Amer. Ceram. Soc., Vol. 88, No. 5, 1337-1340, 2005.

[9] N.Y. Wu, T.C. Holgate, N.V. Nong, N. Pryds, S. Linderoth, High temperature thermoelectric properties of $\mathrm{Ca}_{3} \mathrm{Co}_{4} \mathrm{O}_{9+\delta}$ by auto-combustion synthesis and spark plasma sintering // J. Eur. Ceram. Soc., Vol. 34, 925-931, 2014.

[10] J.W. Park, D.H. Kwak, S.H. Yoon, S.C. Choi, Thermoelectric properties of highly oriented $\mathrm{Ca}_{2.7} \mathrm{Bi}_{0.3} \mathrm{Co}_{4} \mathrm{O}_{9}$ fabricated by rolling process // J. Ceram. Soc. Jap., Vol. 117, No. 5, 643-646, 2009.

[11] I.V. Matsukevich, A.I. Klyndyuk, E.A. Tugova, M.V. Tomkovich, N.S. Krasutskaya, V.V. Gusarov, Synthesis and Properties of Materials Based on Layered Calcium and Bismuth Cobaltites // Rus. J. Appl. Chem. Vol. 88, No. 8, 1241-1247, 2015.

[12] I.V. Matsukevich, A.I. Klyndyuk, E.A. Tugova, A.N. Kovalenko, A.A. Marova, N.S. Krasutskaya, Thermoelectric Properties of $\mathrm{Ca}_{3-x} \mathrm{Bi}_{x} \mathrm{Co}_{4} \mathrm{O}_{9+\delta}(0.0 \leq x \leq 1.5)$ Ceramics // Inorg. Mater., Vol. 52, No. 6, 593-599, 2016.

[13] M. Prevel, O. Perez, J.G. Noudem, Bulk textured $\mathrm{Ca}_{2.5}(\mathrm{RE})_{0.5} \mathrm{Co}_{4} \mathrm{O}_{9} \quad$ (RE: Pr, Nd, Eu, Dy and $\mathrm{Yb}$ ) thermoelectric oxides by sinter-forging // Solid State Sci., Vol. 9, 231-235, 2007.

[14] A.I. Klyndyuk, I.V. Matsukevich, Synthesis and Properties of $\mathrm{Ca}_{2.8} \mathrm{Ln}_{0.2} \mathrm{Co}_{4} \mathrm{O}_{9+\delta}$ ( $\mathrm{Ln}-\mathrm{La}$, Nd, Sm, Tb-Er) Solid Solutions // Inorg. Mater. Vol. 48, No. 10, 1052-1057, 2012.

[15] Y. Wang, Y. Sui, P. Ren, L. Wang, X. Wang, W. Su, H. Fan, Strongly Correlated Properties and Enhanced Thermoelectric Response in $\mathrm{Ca}_{3} \mathrm{Co}_{4-x} \mathrm{M}_{x} \mathrm{O}_{9}(\mathrm{M}=\mathrm{Fe}, \mathrm{Mn}$, and $\mathrm{Cu}$ ) // Chem. Mater., Vol. 22, 1155-1163, 2010.

[16] A.I. Klyndyuk, I.V. Matsukevich, Synthesis, Structure and Properties of $\mathrm{Ca}_{3} \mathrm{Co}_{3.85} \mathrm{M}_{0.15} \mathrm{O}_{9+\delta}(\mathrm{M}-\mathrm{Ni}-\mathrm{Zn}, \mathrm{Mo}, \mathrm{W}, \mathrm{Pb}$, Bi) Layered Thermoelectrics // Inorg. Mater., Vol. 51, No. 9, 944-950, 2015

[17] Y. Song, Q. Sun, L. Zhao, F. Wang, Z. Jiang, Synthesis and thermoelectric power factor of $\left(\mathrm{Ca}_{0.95} \mathrm{Bi}_{0.05}\right)_{3} \mathrm{Co}_{4} \mathrm{O}_{9} / \mathrm{Ag}$ composites // Mat. Chem. Phys., Vol. 113, 645-649, 2009.
Properties of Ceramics Based on Barium-Strontium Metaplumbates // Glass Phys. Chem., Vol. 39, No. 4, 453457, 2013.

[19] Sh. Rasekh, N.M. Ferreira, F.M. Costa, G. Constantinescu, M.A. Madre, M.A. Torres, J.C. Diez, A. Sotelo, Development of a new thermoelectric $\mathrm{Bi}_{2} \mathrm{Ca}_{2} \mathrm{Co}_{1.7} \mathrm{O}_{x}+$ $\mathrm{Ca}_{3} \mathrm{Co}_{4} \mathrm{O}_{9}$ composite // Scripta Mater., Vol. 80, 1-4, 2014.

[20] O. Jankowski, S. Huber, D. Sedmidubsky, L. Nadherny, T. Hlasek, Z. Sofer, Towards highly efficient thermoelectric: $\mathrm{Ca}_{3} \mathrm{Co}_{4} \mathrm{O}_{9+\delta} \cdot n \mathrm{CaZrO}_{3}$ composite // Ceramics-Silikaty, Vol. 58, No. 2, 106-110, 2014.

[21] F. Delorme, P. Diaz-Chao, E. Guilmeau, F. Giovannelli, Thermoelectric properties of $\mathrm{Ca}_{3} \mathrm{Co}_{4} \mathrm{O}_{9}-\mathrm{Co}_{3} \mathrm{O}_{4}$ composites // Ceram. Int., Vol. 41, No. 8, 10038-10043, 2015.

[22] R.K. Gupta, R. Sharma, A.K. Mahapatro, R.P. Tandon, The effect of $\mathrm{ZrO}_{2}$ dispersion on the thermoelectric power factor of $\mathrm{Ca}_{3} \mathrm{Co}_{4} \mathrm{O}_{9} / /$ Physica B., Vol. 483, 48-53, 2016.

[23] X.-D. Zhou, L.R. Pederson, E. Thomsen, Z. Nie, and G. Coffey, Nonstoichiometry and Transport Properties of $\mathrm{Ca}_{3} \mathrm{Co}_{4 \pm x} \mathrm{O}_{9+\delta}(x=0-0.4) / /$ Electrochem. Solid-State Lett., Vol. 12, No. 2, F1-F3, 2009.

[24] D. Sedmidubsky, V. Jakes, O. Jankovsky, J. Leitner, Z. Sofer, J. Hejtmanek, Phase equilibria in Ca-Co-O system // J. Solid State Chem., Vol. 194, 199-205, 2012.

[25] A.I. Klyndyuk, Ye.A. Chizhova, Thermoelectric properties of the layered oxides $\mathrm{LnBaCu}(\mathrm{Co}) \mathrm{FeO}_{5+\delta}(\mathrm{Ln}=\mathrm{La}, \mathrm{Nd}, \mathrm{Sm}$, Gd) // Funct. Mater., Vol. 16, No. 1, 17-22, 2009.

[26] A.C. Masset, C. Michel, A. Maignan, M. Hervieu, O. Toulemonde, F. Studer, B. Raveau, Misfit-layered cobaltite with an anisotropic giant magnetoresistance: $\mathrm{Ca}_{3} \mathrm{Co}_{4} \mathrm{O}_{9} / /$ Phys. Rev. B., Vol. 62, No. 1, 166-175, 2000-I.

[27] K. Iwasaki, H. Yamane, J. Takahashi, S. Kubota, T. Nagasaki, Y. Arita, Y. Nishi, T. Matsui, M. Shimada, Influence of $\mathrm{Bi}$ and $\mathrm{Cu}$ substitutions on the power factor of $\mathrm{Ca}_{3} \mathrm{Co}_{2} \mathrm{O}_{6} / /$ J. Phys. Chem. Solids, Vol. 66, 303-307, 2005.

[28] M. Mikami, R. Funahashi, The effect of element substitution on high-temperature thermoelectric properties of $\mathrm{Ca}_{3} \mathrm{Co}_{2} \mathrm{O}_{6}$ compounds // J. Solid State Chem., Vol. 178, 1670-1674, 2005.

[29] Powder Diffraction File. Swarthmore: Joint Committee on owder Diffraction Standard: Card № 00-042-1467.

[18] E.A. Chizhova, A.I. Klyndyuk, Synthesis and Thernoelectric 